\title{
ICT utilization of Extension Personnel in Saurashtra Region of Gujarat
}

\author{
Rose Mathews* and N. B. Jadav \\ Department of Agriculture Extension, COA, JAU, Junagadh, Gujarat, India \\ *Corresponding author
}

\begin{abstract}
A B S T R A C T

\begin{tabular}{|l|}
\hline Key w o r d s \\
Extension \\
personnel, \\
ICT utilization \\
\hline Article Info \\
\hline $\begin{array}{l}\text { Accepted: } \\
\text { 20 June 2020 } \\
\text { Available Online: } \\
\text { 10 July 2020 }\end{array}$ \\
\hline
\end{tabular}

ICTs can be utilized in agriculture for providing relevant and timely farm information to the farmers. Agricultural extension personnel have to be expert in using various ICTs. The present study was conducted among 120 extension personnel in Saurashtra region of Gujarat. Six districts were selected randomly and from each districts respondents were selected proportionately. Fifteen different ICT tools were selected for the study. It was found that more than half (65.00) of the extension personnel had medium extend of ICT utilization followed by 20.00 per cent high and 15.00 per cent low level of utilization. Use of computer was topped in the above $15 \mathrm{hrs} /$ week duration. Duration of e-mail usage was stood first in 10-15 hrs category. Telephone usage (50.00 per cent) topped in 5-10 hrs/week category. Duration of utilization of e-journals ( 95.83 per cent) was found highest in 1-5 hrs/ week category. Majority (97.50 per cent) of the extension personnel use enewspaper and e-agricultural magazines for knowledge or recent information. 72.50 per cent use mobile phone for advisory services, 14.17 per cent use kiosk for training and teaching, 79.17 per cent use e-mail for sending reports, 94.17 per cent use mobile phone for organizational communication.
\end{abstract}

\section{Introduction}

As the part of 'Digital India' initiative of government of India, the agriculture sector is also being digitalised. Agricultural extension personnel are the important category of change agents who are supposed to become the part of it. Extension personnel can employ various ICTs in their professional life.

They can also motivate the farmers for the effective utilization of ICTs and thus the benefits of ICT can be reached up to the grass root level. So it is important to analyse the existing situation of ICT usage among extension personnel. Keeping this in vision the present study was conducted to assess the ICT utilization of extension personnel in Saurashtra region of Gujarat.

\section{Materials and Methods}

The present study was conducted in the Saurashtra region of Gujarat state. There are eleven districts in Saurashtra region out of which six districts were selected randomly. Respondents were selected proportionate to the total strength of extension personnel from each district. The sample consisted of 120 respondents for the study. The data was 
collected through personal interview or mailed questionnaire.

\section{Results and Discussion}

Fifteen ICTs were selected for the study. The ICT utilization was studied as the extend of ICT utilization, duration of ICT utilization and purpose of ICT utilization.

\section{Extend of ICT utilization}

Extend of ICT utilization means the range over which the extension personnel are exposed to various ICTs. The data regarding extend of ICT utilization by the extension personnel is shown in the Table 1 .

It was observed that majority (65.00 per cent) of the extension personnel had medium extend ICT utilization followed by 20.00 per cent had high level extend of ICT utilization and 15.00 per cent had low level extend of ICT utilization.

\section{Duration of ICT utilization by extension personnel}

In order to study the duration of ICT utilization, duration per week in hours was measured and the obtained data is presented in the Table 2.

It was seen that the duration of computer usage was the highest (16.67 per cent) in the above 15 hrs/week category followed by internet (9.17 per cent) and telephone (8.33 per cent). None of the extension personnel used kiosk and e-journals above 15 hrs/ week.

Duration of e-mail utilization stood first in 10-15 hrs/ week category. 30.00 per cent of the extension personnel use e-mail 10-15 hrs/week. An equal per cent (23.33 per cent) of the respondents were using internet and enewspaper 10-15 hrs/ week followed by television (18.33 per cent). None of the respondents utilized e-journals 10-15 hrs/ week.

It is also evident from the table that duration of utilization of e-journals topped in 1-5 hrs/week category followed by video conferencing (87.50 per cent) and eagricultural magazines (85.83 per cent). Telephone was utilized by only 31.67 per cent of the extension personnel under this category.

\section{Purpose of ICT Utilization by Extension Personnel}

Three purposes were taken for this study namely personal, transfer of technology and organizational purposes. The data regarding the purpose of utilization is given in the Table 3.

It was found that an equal per cent ( 97.50 per cent) of the respondents use e-newspaper and e-agricultural magazines for knowledge/recent information followed by internet and e-journals (94.17 percent). 91.67 percent of the respondents were utilizing kiosk for knowledge/ recent information.

The purpose of transfer of technology is discussed under three sub heads namely advisory services, training / teaching and for sharing input agencies. Less than three-fourth (72.50 per cent) of the respondents were using mobile phone for advisory services followed by telephone (65.00 per cent) and radio (32.50 per cent). 14. 17 per cent of the respondents were using kiosk for training and teaching followed by 9.17 per cent e-newspaper and 4.17 per cent video conferencing.

For sharing input agencies an equal per cent (3.33 per cent) of the respondents were using radio, television and e-agricultural magazines. 
Table.1 Distribution of the extension personnel according to their utilization of ICT ( $\mathrm{n}=120$ )

\begin{tabular}{|c|l|c|c|}
\hline Sr. No. & Utilization of ICT & Frequency & Percentage \\
\hline $\mathbf{1 .}$ & Low (below 41.51) & 18 & 15.00 \\
\hline $\mathbf{2 .}$ & $\begin{array}{l}\text { Medium (41.51- } \\
\text { 72.58) }\end{array}$ & 78 & 65.00 \\
\hline 3. & High (above 72.58) & 24 & \\
\hline Total & & $\mathbf{1 2 0}$ & $\mathbf{1 0 0 . 0 0}$ \\
\hline Mean=57.04 & & S.D $=15.53$ \\
\hline
\end{tabular}

Table.2 Distribution of the extension personnel according to their duration of utilization of ICT per week $(n=120)$

\begin{tabular}{|c|c|c|c|c|c|c|c|c|c|}
\hline \multirow[t]{2}{*}{$\begin{array}{l}\text { Sr. } \\
\text { No }\end{array}$} & \multirow[t]{2}{*}{ ICTs } & \multicolumn{2}{|c|}{ 1-5 hrs/week } & \multicolumn{2}{|c|}{ 5-10hrs/week } & \multicolumn{2}{|c|}{$\begin{array}{c}10-15 \\
\text { hrs/week }\end{array}$} & \multicolumn{2}{|c|}{$\begin{array}{l}\text { Above } 15 \\
\text { hrs/week }\end{array}$} \\
\hline & & Freq. & $\%$ & Freq. & $\%$ & Freq. & $\%$ & Freq. & $\%$ \\
\hline 1. & Radio & 97 & 80.83 & 10 & 8.33 & 8 & 6.67 & 5 & 4.17 \\
\hline 2. & Television & 56 & 46.67 & 36 & 30.00 & 22 & 18.33 & 6 & 5.00 \\
\hline 3. & Telephone & 38 & 31.67 & 60 & 50.00 & 12 & 10.00 & 10 & 8.33 \\
\hline 4. & Mobile phone & 52 & 43.33 & 47 & 39.17 & 18 & 15.00 & 3 & 2.50 \\
\hline 5. & Computer & 51 & 42.50 & 28 & 23.33 & 21 & 17.50 & 20 & 16.67 \\
\hline 6. & Internet & 58 & 48.33 & 23 & 19.17 & 28 & 23.33 & 11 & 9.17 \\
\hline 7. & e-mail & 65 & 54.17 & 15 & 12.50 & 36 & 30.00 & 4 & 3.33 \\
\hline 8. & $\begin{array}{l}\text { Web based search } \\
\text { engine }\end{array}$ & 72 & 60.00 & 24 & 20.00 & 21 & 17.50 & 3 & 2.50 \\
\hline 9. & $\begin{array}{l}\text { Web based } \\
\text { agricultural } \\
\text { information portals }\end{array}$ & 79 & 65.83 & 28 & 23.33 & 9 & 7.50 & 4 & 3.33 \\
\hline 10. & DSS & 102 & 85.00 & 9 & 7.50 & 5 & 4.17 & 4 & 3.33 \\
\hline 11. & Video conferencing & 105 & 87.50 & 10 & 8.33 & 3 & 2.50 & 2 & 1.67 \\
\hline 12. & Kiosk & 97 & 80.83 & 15 & 12.50 & 8 & 6.67 & 0 & 0.00 \\
\hline 13. & e-newspaper & 79 & 65.83 & 10 & 8.33 & 28 & 23.33 & 3 & 2.50 \\
\hline 14. & e-journals & 115 & 95.83 & 5 & 4.17 & 0 & 0.00 & 0 & 0.00 \\
\hline 15. & $\begin{array}{l}\text { e-agricultural } \\
\text { magazines }\end{array}$ & 103 & 85.83 & 10 & 8.33 & 5 & 4.17 & 2 & 1.67 \\
\hline
\end{tabular}


Table.3 Distribution of the extension personnel according to their purpose of utilization of ICT $(n=120)$

\begin{tabular}{|c|c|c|c|c|c|c|c|c|c|c|c|c|c|}
\hline \multirow{4}{*}{$\begin{array}{l}\text { Sr. } \\
\text { No }\end{array}$} & \multirow[t]{4}{*}{ ICTs } & \multicolumn{12}{|c|}{ Purpose of utilization } \\
\hline & & \multirow{2}{*}{\multicolumn{2}{|c|}{$\begin{array}{l}\text { Personal } \\
\text { Knowledge/ } \\
\text { recent } \\
\text { information }\end{array}$}} & \multicolumn{6}{|c|}{ Transfer of technology } & \multicolumn{4}{|c|}{ Organizational } \\
\hline & & & & \multicolumn{2}{|c|}{$\begin{array}{l}\text { Advisory } \\
\text { services }\end{array}$} & \multicolumn{2}{|c|}{$\begin{array}{l}\text { Training/ } \\
\text { teaching }\end{array}$} & \multicolumn{2}{|c|}{$\begin{array}{l}\text { For sharing } \\
\text { input } \\
\text { agencies }\end{array}$} & \multicolumn{2}{|c|}{$\begin{array}{l}\text { Preparing/sending } \\
\text { reports }\end{array}$} & \multicolumn{2}{|c|}{$\begin{array}{l}\text { Organizational } \\
\text { communication }\end{array}$} \\
\hline & & Freq. & $\%$ & Freq. & $\%$ & Freq. & $\%$ & Freq. & $\%$ & Freq. & $\%$ & Freq. & $\%$ \\
\hline 1 & Radio & 95 & 79.17 & 39 & 32.50 & 3 & 2.50 & 4 & 3.33 & - & - & - & - \\
\hline 2 & Television & 110 & 91.67 & 32 & 26.67 & 3 & 2.50 & 4 & 3.33 & - & - & - & - \\
\hline 3 & Telephone & 37 & 30.83 & 78 & 65.00 & - & - & - & & - & - & 89 & 74.17 \\
\hline 4 & Mobile phone & 97 & 80.83 & 87 & 72.50 & - & - & - & & - & - & 113 & 94.17 \\
\hline 5 & Computer & 81 & 67.50 & 7 & 5.83 & - & - & - & & 93 & 77.50 & - & - \\
\hline 6 & Internet & 113 & 94.17 & 9 & 7.50 & - & - & - & & 81 & 67.50 & 5 & 4.17 \\
\hline 7 & e-mail & 21 & 17.50 & 5 & 4.17 & - & - & - & & 95 & 79.17 & 98 & 81.67 \\
\hline 8 & $\begin{array}{l}\text { Web based search } \\
\text { engine }\end{array}$ & 115 & 95.83 & 5 & 4.17 & - & - & - & & - & - & - & - \\
\hline 9 & $\begin{array}{l}\text { Web based } \\
\text { agricultural } \\
\text { information } \\
\text { portals }\end{array}$ & 93 & 77.50 & 3 & 2.50 & - & & - & & - & - & - & - \\
\hline 10 & DSS & 93 & 77.50 & 23 & 19.17 & - & & - & & - & - & - & - \\
\hline 11 & $\begin{array}{l}\text { Video } \\
\text { conferencing }\end{array}$ & 71 & 59.17 & 13 & 10.83 & 5 & 4.17 & 3 & 2.50 & - & - & - & - \\
\hline 12 & Kiosk & 110 & 91.67 & 11 & 9.17 & 17 & 14.17 & - & & - & & - & - \\
\hline 13 & e-newspaper & 117 & 97.50 & 14 & 11.67 & 11 & 9.17 & - & & - & & - & - \\
\hline 14 & e-journals & 113 & 94.17 & 9 & 7.50 & - & & - & & - & & - & - \\
\hline 15 & $\begin{array}{l}\text { e-agricultural } \\
\text { magazines }\end{array}$ & 117 & 97.50 & 17 & 14.17 & - & 2.50 & - & 3.33 & - & & - & - \\
\hline
\end{tabular}


Under the organizational purpose two sub heads are given namely preparing or sending reports and organizational communication. Majority (79.17 per cent) of the respondents were using email for preparing/ sending reports followed by computer (77.50 per cent) and internet (67.50 per cent). 94.17 per cent of the respondents were using mobile phone for organizational communication followed by e-mail (81.67 per cent) and telephone (74.17 per cent).

The ICTs can be effectively used in agricultural extension system. Extension personnel are using various ICTs for different purposes. From the present study it can be concluded that majority (65.00 per cent) of the extension personnel had medium extend of ICT utilization. Computer stood first (16.7 per cent) in the duration of utilization (above 15hrs/week). Under 10-15 hrs/week, duration of e-mail stood first (30.00 per cent). Duration of utilization of e-journals topped in 1-5 hrs/ week category. The extension personnel use ICTs for various purposes namely personal, transfer of technology and organizational purposes. Equal per cent ( 97.50 per cent) of the respondents use e-newspaper and e-agricultural magazines for knowledge/recent information. Majority (72.50 per cent) use mobile phone for advisory services.79.17per cent use e-mail for preparing or sending reports. Majority (94.17 per cent) use mobile phone for organizational communication.

\section{References}

Agha, N.; Ghanghas, B. S. and Chahal, P. K. 2018. Use of Information and Communication Technology by extension personnel to disseminate agricultural information. International Journal of Current Microbiology and Applied Sciences, 7(4): 1369-1376.

Chithra, G. 2015. Strategies for capacity building of extension personnel for using information technologies. M. Sc. (Agri.) Thesis (Unpublished), KAU, Kerala.

Roshan, B. 2015. Extent of utilization of ICT tools among field veterinarians of Andhra Pradesh. M.V.Sc. Thesis (Unpublished), SVVU, Tirupati.

Sharma, R. 2018. Utilization pattern of Information and Communication Technologies (ICTs) among scientists of KVKs in Madhya Pradesh and Chhattisgarh. Ph. D. Thesis (Unpublished), RVSKVV, Gwalior.

Verma, S. R. and Sharma, F. L. 2013. Application of information and communication technologies in agriculture by extension personnel. Journal of Extension Systems, 29(2):13-28.

\section{How to cite this article:}

Rose Mathews and Jadav, N. B. 2020. ICT utilization of Extension Personnel in Saurashtra Region of Gujarat. Int.J.Curr.Microbiol.App.Sci. 9(07): 2298-2302. doi: https://doi.org/10.20546/ijcmas.2020.907.267 